\title{
BM 計保守改善の取組について
}

\author{
王子製紙株式会社 苫小牧工場施設部 上 村 登 貴 雄
}

\section{Activities to Improve Quality Control System Maintenances}

\section{Tokio Uemura}

Tomakomai Mill, Oji Paper Co., Ltd

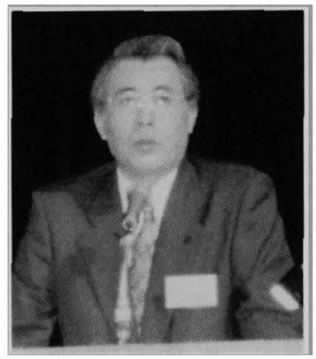

Recently we should realize that the need and importance of Quality Control System (BM measurement system) would be invaluable for the automatic control of instrument systems regard to the final product and quality management in the paper and pulp production process of the process industry.

The importance of the maintenance and reaper job for the overall system to keep the measurement accuracy and stable production to meet the quality demand through various things like many grades and small productions has been increasing. However, the actual situation would be that it takes a long time to get a reliable system from the standpoint for both hardware and software of the system itself after the installation. So some examples from the good results will be shown in this report because of many requirements to improve the life and working procedure for the parts.

分類： $\mathrm{M}_{11}$ 駆動装置および付属設備， $\mathrm{V}_{3}$ 紙パルプ工程計器およびセンサ

1.はじめに

現在, 製秖工場において BM 計は品質維持・生産 性確保に必要不可欠なッールであり, 測定精度が高く, かつ制御性・長期安定性・保守性に優れていることが 肝要である。

しかし，世代交代をくりかえしながら発展してきた にも拘わらず，七ンサー・フレーム駆動系及び制御系 も含めたシステム全体にわたって，保守する立場の視 点にたつと機能上まだまだ改善を必要とする点が多く, 日常保全においてこれらをテーマとして取組み，成果 を上げた改善事例があるので報告する。

\section{2. $\mathrm{BM}$ システム導入経緯}

苫小牧工場の BM 計導入経緯は，1969 年横河電機 製 $\mathrm{B} / \mathrm{M} 700$ 型が最初で，坪量・水分流れ方向制御の
みであったが，以後抄紙機の増設や各種新型センサー の開発, 幅方向制御の要求の他, 測定精度 - 制御性向 上の観点から, 横河電機製 CENTUM-DL 型, ハネウ エル・メジャレックス製（以降メジャレックス） MX2000 型が探用された（表 1)。

その後、ケ゚ートロールサイズブレス設置に伴うフレ 一ム・センサーの增設や制御機能の多様化, データー 処理高速化のニーズによる機種変更を経て, 現在主流 の機種は, 横河電機製 B/M-7000 XL,メジャレッ クス製 MX-OPEN システムである。

\section{3. $\mathrm{BM}$ 計関連故障件数推移}

本来 BM 計は, 連続操業に影䈉を与えず安定した ものでなければならないが, 現実は戦しくシステム導 入直後の初期トラフルは別にしても, 恒久対策迄 4〜 5 年かかる場合がある。 


上村 登貴雄

表 1 BM システム導入経緯

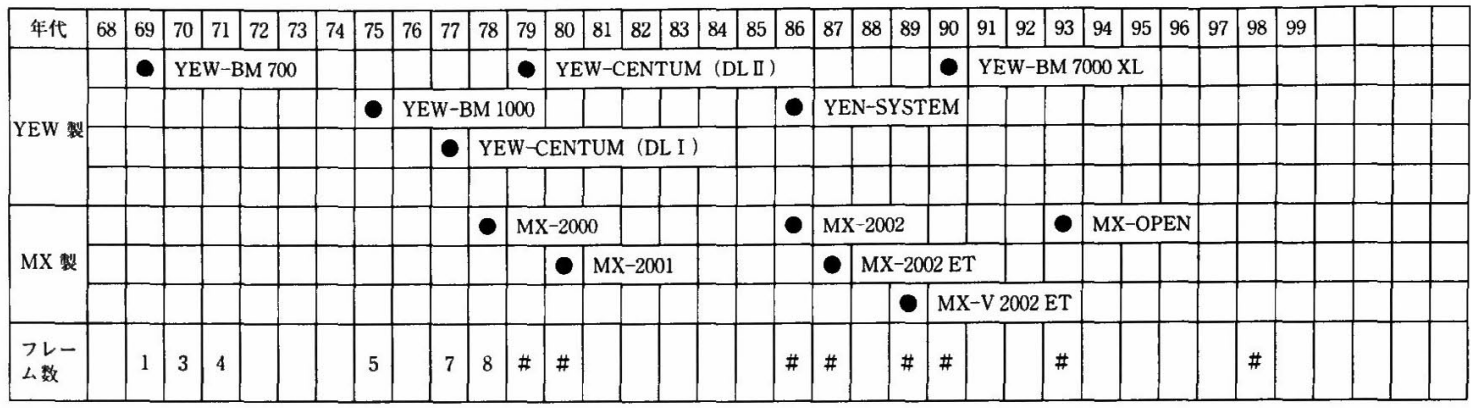

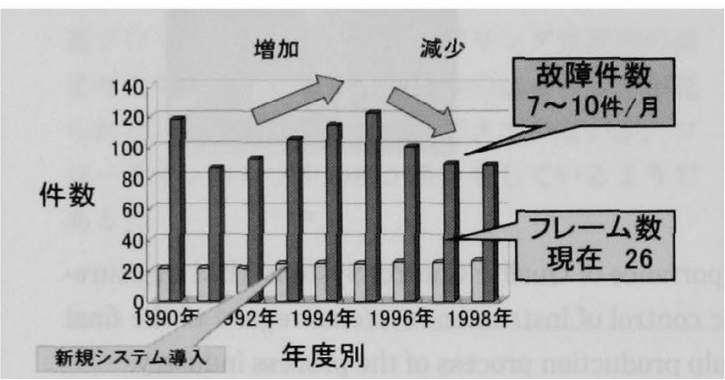

図 $1 \mathrm{BM}$ システムフレーム数・故障件数推移

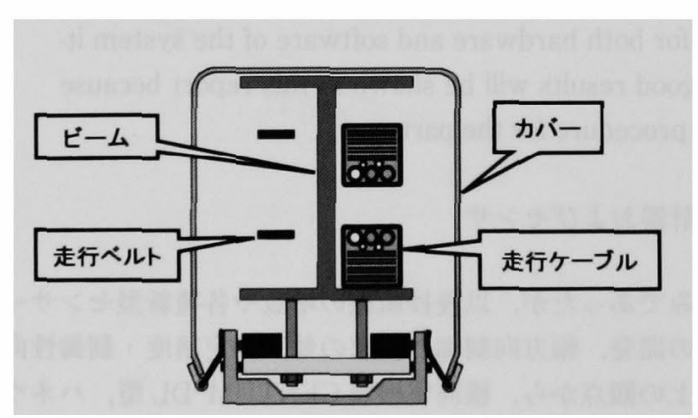

図 2 旧型 I ビーム構造

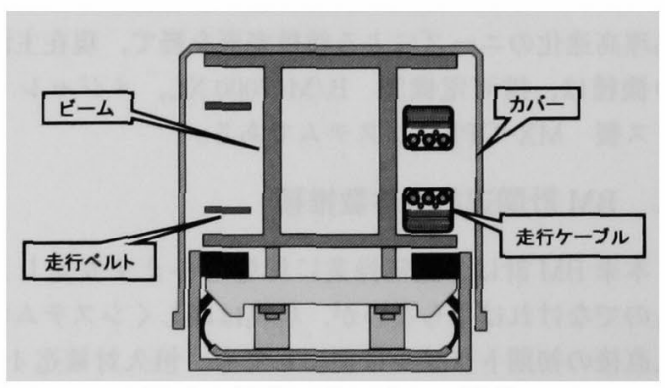

図 3 新型ツインビーム構造

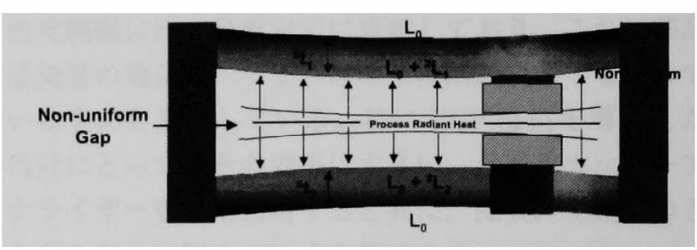

- Change in Length with Change in Temperature: ${ }^{2} L=\alpha \times L_{0} \times{ }^{2}$

- Varying Air Column B. W. Measurement Error (at 50DC [122bF]): \begin{tabular}{ll}
$0.1 \mathrm{~mm}$ & B.W. Error \\
\hline $0.11 \mathrm{gsm}$
\end{tabular}

図 4 スキャナーフレームが受ける熱による影響

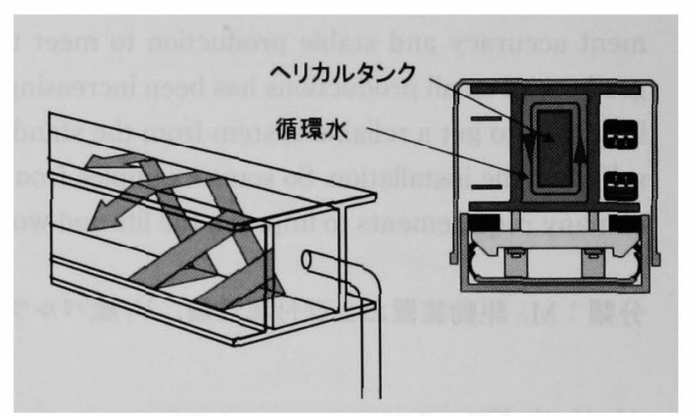

図 5 フレーム温度均等化

過去 10 年間の $\mathrm{BM}$ 計関連故障件数の推移は, 年間 約 80〜 120 件, 月平均の故障件数は概ね, 7〜10 件で 推移している（図 1)。

\section{4. 保守改善実施例}

\section{4. $1 \mathrm{MX}-\mathrm{BM}$ フレーム歪み防止対策}

メジャレックス製 $\mathrm{BM}$ 計フレーム構造は，旧型が I ビーム, 新型はツインビームで内部を空洞構造とした 特徵を持っている（図2，図 3)。

新型の特徴であるフレーム空润部には, 螺旋構造の ポリタンクが挿入され，その周りにはTES（THERMAL EQUALIZATION SYSTEM：熱均等化）液と 
称される循環水が満たされており，ポンプにてフレー ム内部を循環している。

この液を循環させる目的は, フレーム上下・左右の 熱分布を一様にして, 熱によるフレームの歪みを防止 するためであり，12〜 $13 \mathrm{~m}$ 程度のフレーム長を有す るシステムには適した構造である(図 4, 図5)。

TES 液はフレーム $1 \mathrm{~m}$ 当たり $25 l$ 入り, $12 \mathrm{~m}$ のフ レーム長の場合上下合計で約 600 入っている が, 1993 年システム導入直後より循環水を頻繁に補

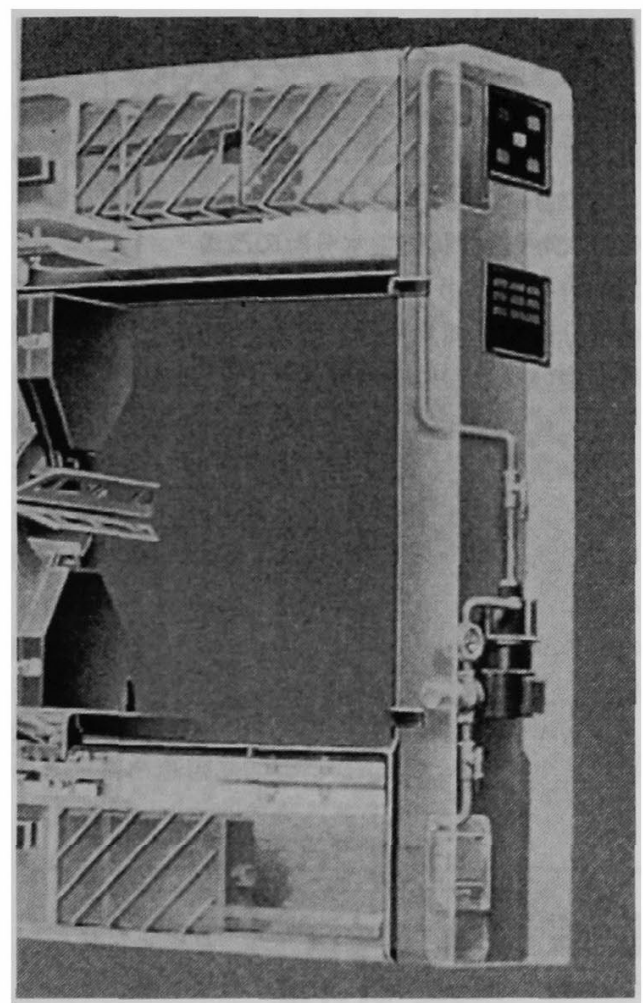

図 6 フレームスタンド部

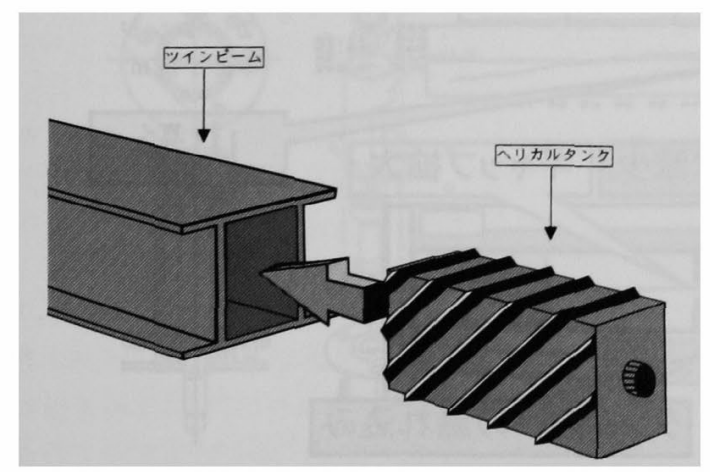

図 7 ッインビームとヘリカルタンク
充する事態が生じ, 一回平均 $15 l$, 年間約 $250 l$ 補給 しなければならなかった（図6，図7，図8）。

循環水減少の原因は, TES 液の水圧により空洞構 造であるヘリカルタンク中央部に亀裂が入りタンク内 部に液が流れ込むためであった。

1）メーカーで実施した対策

(1)ヘリカルタンク中央に補强材設置（図 9)

(2)補強材中間に仕切板設置（図 10）

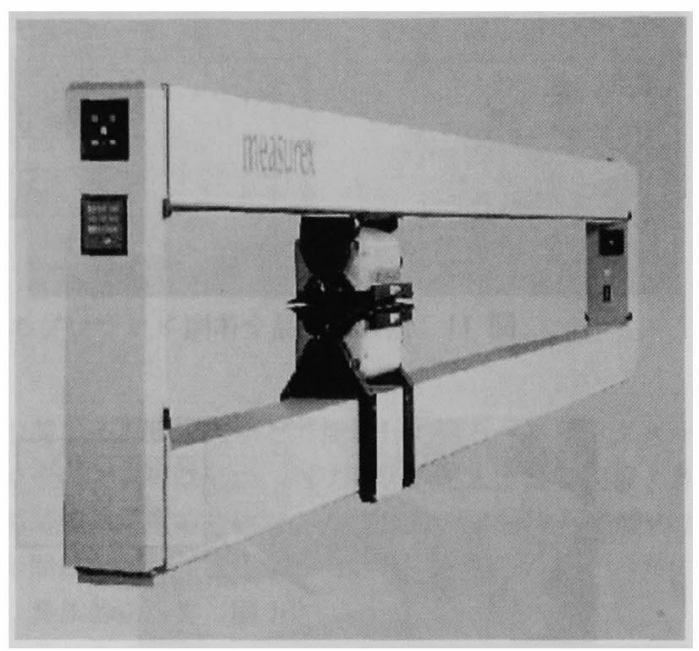

図８フレーム全体

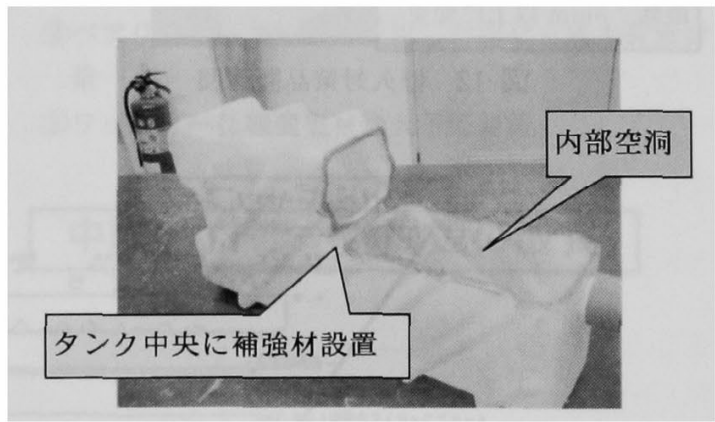

図 9 メーカーで実施した対策 1

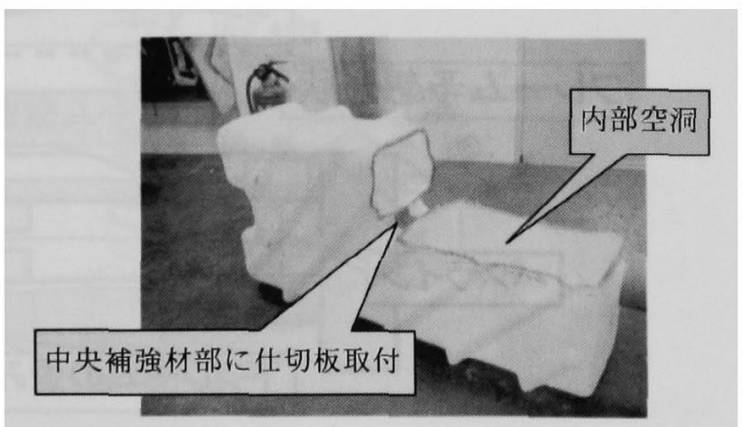

図 10 メーカーで実施した対策 2 


上村登貴雄

しかしいずれも効果なく，当方よりヘリカルタンク 内に発砲ウレタンを充填した試作品をメーカーに供給 し再度改造依頼, 同時に従来最低 $1 \mathrm{~mm}$ であったタン

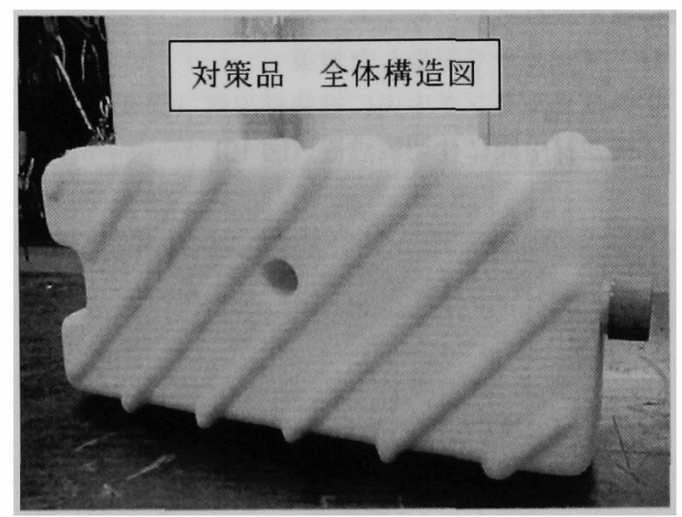

図 11 恒久対策品全体図



図 12 恒久对策品断面図
クコーナー部を $5 \mathrm{~mm}$ まで厚くした仕様とし，1998 年新規システムにて採用, 約 1 年間の経過観察を経て 恒久对策としたがこの間 5 年間を要した（図 11, 図 12)。

2）対策品使用前後の比較

【従来品使用時】

タンク内への循環水漏れ込みがある場合, 下フレー ムに循環水が集中し、フレーム中央を下げることによ ク,ヘッド間ギャップZと, 坪量プロファイルは山 形となっている(図 13)。

【対策品使用後】

恒久対策品交換後の各プロファイルはほほフラット であり, 交換前後の比較は $\mathrm{Z}$ 值で約 $1.2 \mathrm{~mm}$ 坪量平 均値で約 $0.38 \mathrm{~g}$ 修正され, 安定した測定結果を得る ことができた（図 14）。

\section{2 横河電機製同軸水分計の改善}

1996 年 4 月より新規採用した BM-7000 XL 型に搭 載の水分計は, 従来使用していた 3 波長タイプと同じ 原理を用いた近赤外線吸収方式で 4 波長同軸水分計で あるが, 稼働後 3 ケ月でフィルターホイル回転機構の ベアリンク焼付きにて測定不能トラブルが発生した。

ベアリンク焼き付きの原因はオイル切れとのメーカ 一見解であったが, その後入手した各単体部品を調査 したところ, 全てのべアリングにガタ付きがあり, 新 品のユニットとして組み付けた場合でも使用直後振動 の発生につながるなど問題があった（図 15）。

メーカー設計担当と検討を重ね, スピンドル軸周辺·

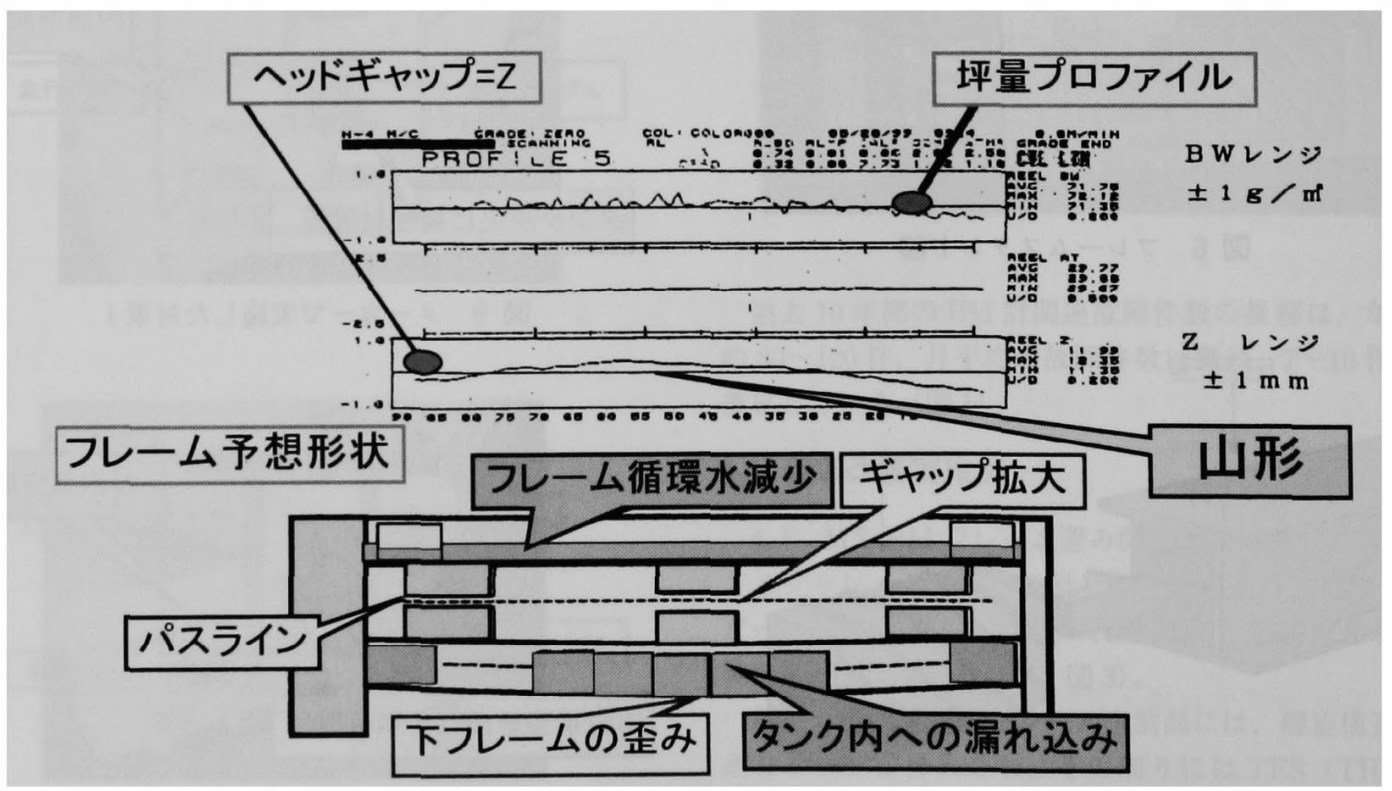

図 13 従来品使用時のプロファイル 


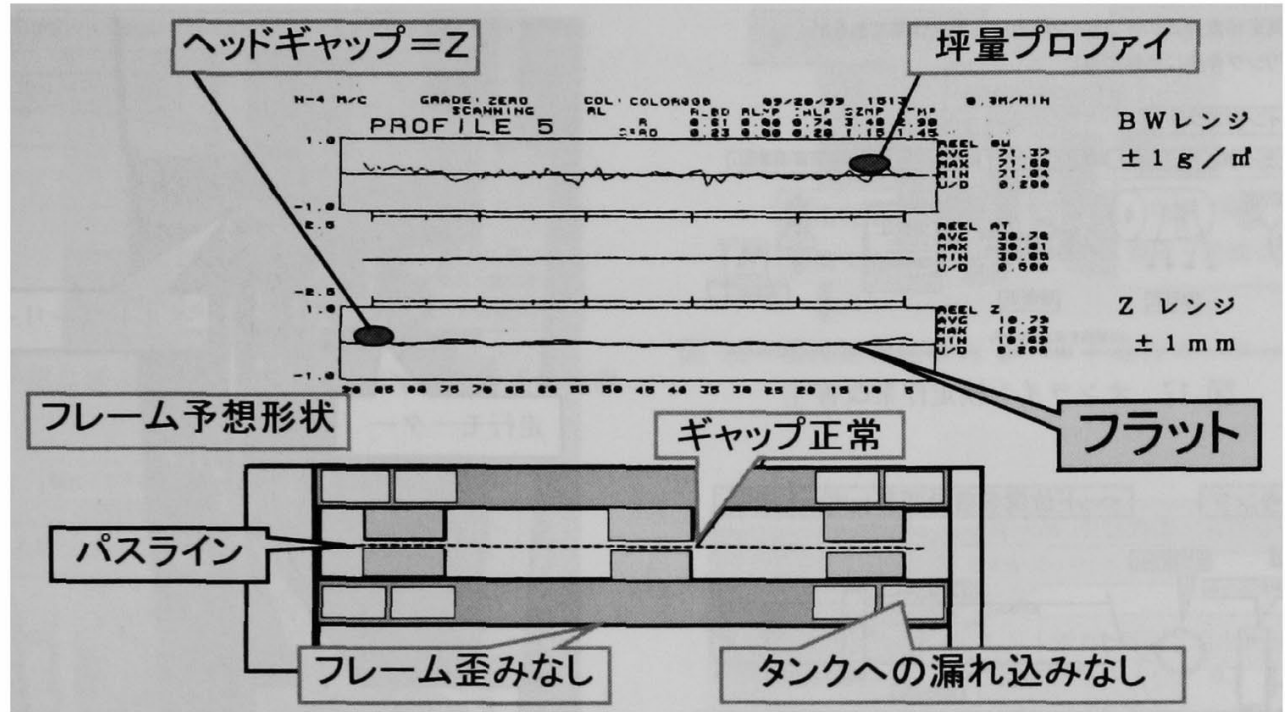

図 14 対策品使用時のプロファイル

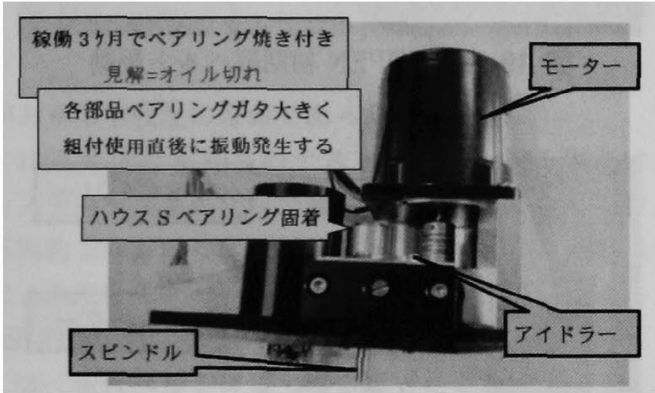

図 15 横河電機製同軸水分計ソースヘッド全体図

\section{スピンドル軸周辺部分の改良}

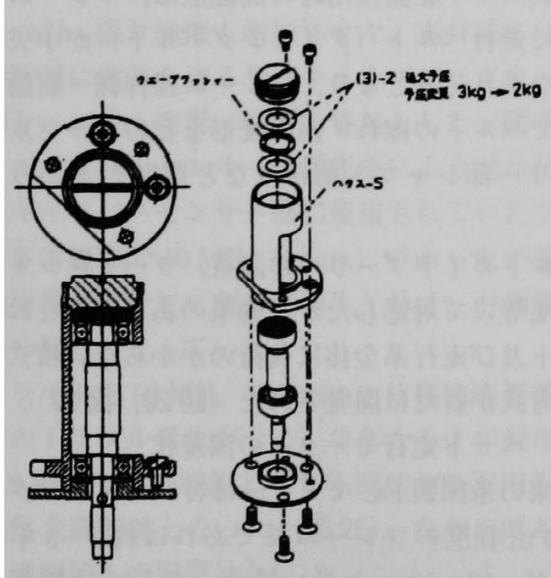

中間アイドラー部などで使用しているべアリングメー カーの変更をはじめ, ベアリング圧入方法の改善・各 部品製作精度の強化などを実施後，メーカー推奨の 1 年間は問題なく稼働するセンサーとなった。

具体的な改善（図 16）

(1)ベアリングメーカー, 内部腙間仕様変更 $(\mathrm{CN} \rightarrow$ C 3）軸公差変更 $=$ 隙間過小対策

(2)ベアリング圧入治具を使用した組立 $=$ 過大荷重対 策

(3)ワッシャー仕様変更 $=$ 過大予圧対策

\section{中間アイドラ一部周辺の改良}

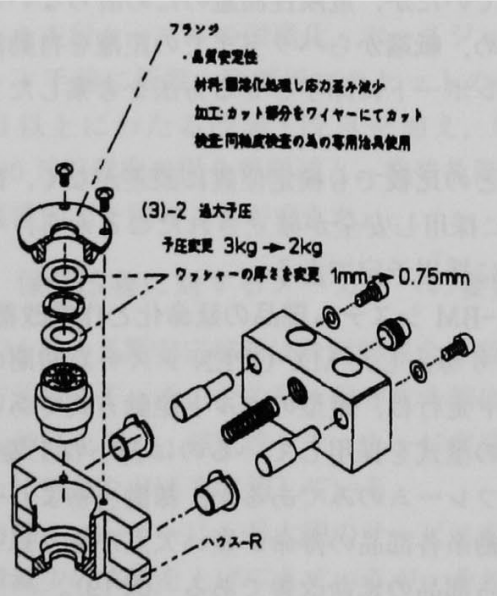

図 16 
BM計測定精度確認のオンライン検定は主要な作莱であるが サンプリング作業に危脸が多い

\section{オンライン模定フロー}



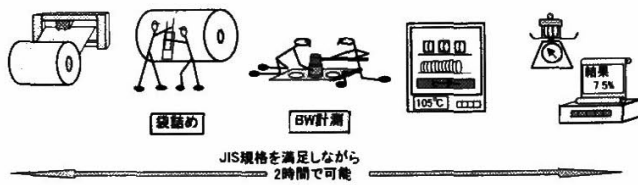

図 17 オンライン検定作業改善

\section{マーキンク］位置を自動演算レポート的字}

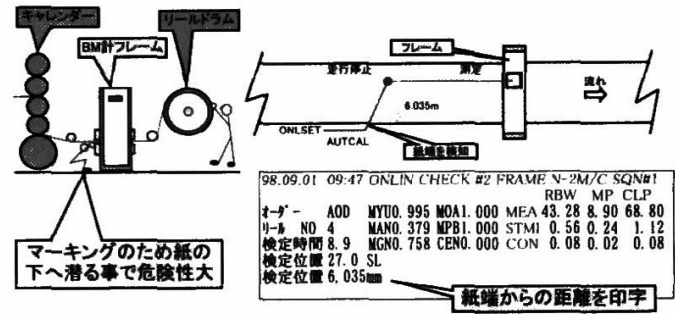

図 18 作業とデータ

\section{3 オンライン検定作業改善}

$\mathrm{BM}$ 計測定精度確認のオンライン検定作業は, 我々 の主要な作業の一つであり過去幾度となく作業改善を 実施, JIS 規格を満足させながら準備から水分結果出 しまで従来一昼夜かけていたものが，約 2 時間で行え るなど成果を上げたが，サンプリング作業は危険が多 い作業であり安全に行える方法はないか改善案を検討 した (図 17)。

サンプル採取のため検出器の測定位置を正確に知る 方法は各種あり，従来我々は紙の下へ潜り直接紙にマ 一キンクしていたが，危険性回避のため潜らないこと を前提に進め，紙端からへッドまでの距離を自動演算 により検定レポートに印字させる方法を考案した（図 18)。

従来方式との比較でも検定位置に嗢差がなく，既に 3 システムに採用し安全が確立されたことから，今後 全システムに採用予定である。

\subsection{MX-BM システム部品の延命化と作業改善}

1993 年より導人した MX-OPEN システム初期の七 ンサーヘッド走行は，綎型のベルト駆動方式である。

国内でこの型式を採用しているのは苫小牧工場の 3 システム 6 フレームのみであるが，稼㗢当初よりセン サー及び駆動系各部品の寿命が短い欠点があり以下の 事例はこれら部品の延命改善である（図 19）。

（1）センサーヘッド駆動方式の変更

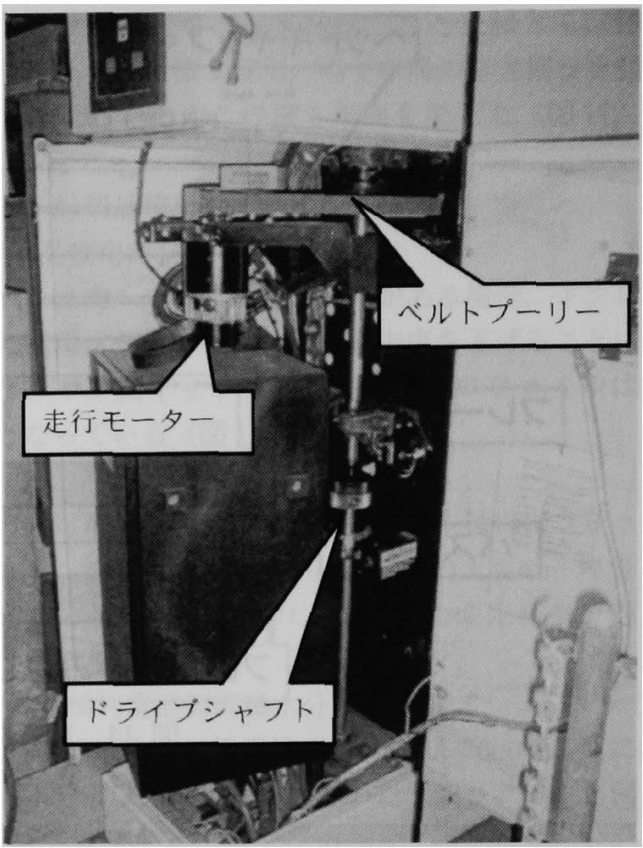

図 19 MX-OPEN 初期縦ベルト駆動

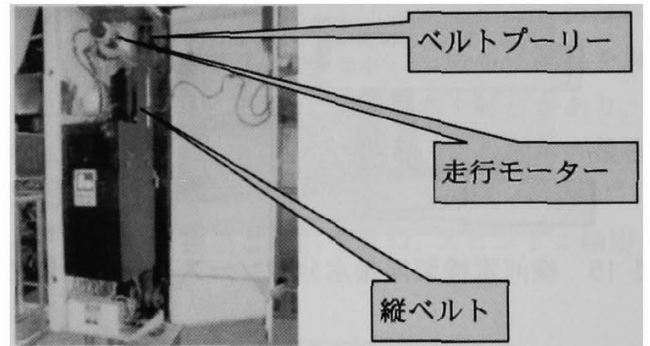

図 $20 \mathrm{MX}-\mathrm{OPEN}$ 横式ベルト駆動ドライブ全体図

絴式ベルト駆動採用時の問題点は, フレーム長が長 い故に走行ベルト（タイミングベルト）が中央付近で 大きな垂れ込みとなり, フレーム操作側・駆動側両サ イドでベルトの擦れ・歯山変形などのトラブルの他, プーリー部シャフト曲がりなど問題が多かった（図 21)。

ベルトガイドプーリーの設置, プーリーシャフト形 状変更等にて対応したが，効果のある改善とはならず， ベルト及び走行系全体に負荷のかからない横式ベルト 駆動方式が新たに開発された（図 20，図 22）。

（2）へッド走行モーターの国産化

従来の米国製 DC モーターは特にベアリング部が弱 く，9m 程度のフレーム長であれば約 2 3 年使用で きたが, 12〜13 m と長い場合, あるいは数多くのセ ンサーを搭載した重い新型ヘッドには強度的に弱い面 


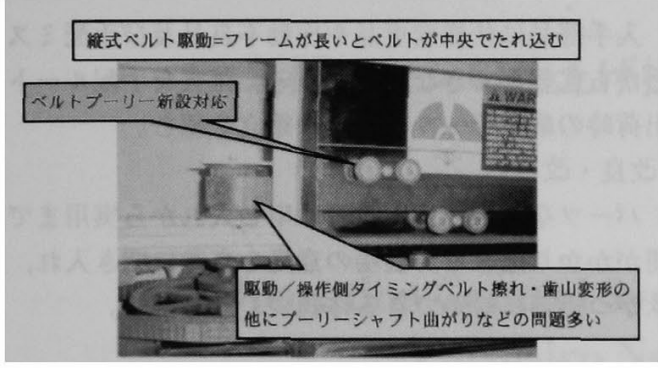

図 21 部品延命化事例-1 MX-OPEN 駆動方式変更前

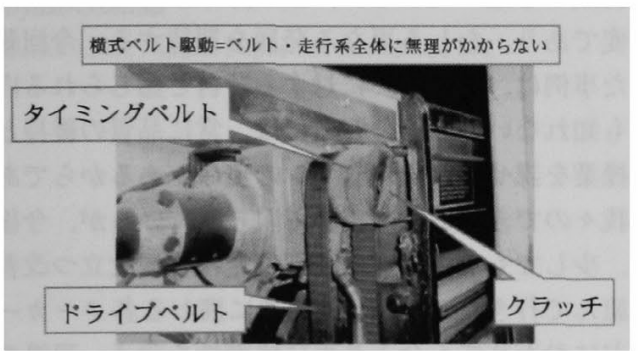

図 22 部品延命化-1 MX-OPEN 駆動方式変更後

があり半年程度の寿命であった。

1995 年国産試作品のテスト連用から約 1 年かけ全 システムを国産品化し, 最長 3 年の使用可能となり, 年間約 300 万円程度の経費節減となった。また軽量化 により取替作業の負荷軽隇と時間短縮が可能となった (図 23)。

（3）走行ベルト材質・構造変更による延命化

従来の走行ベルトは, 標準ウレタン製で, 引っ㲀り 強度及びプーリー部での急激な曲げには弱く, 変形や 切断を幾度となく繰り返していた。

材質を高温度用ウレタンのブラックベルトに変更, 挿入ワイヤー本数を増加仕様とし, 全体に柔軟性を持 たせかつ引っ張り強度も增加させた。走行系には負荷 上昇時瞬時に電源を切るサーキットプロテクターの併 用も図り,ベルト変形・切断を皆無とした（図 24）。

(4) キャリパーセンサー仕様変更による延命化

従来キャリパーセンサー部に使用されていたフェラ イト厚さは標準で $40 \mathrm{MIL}(1 \mathrm{~mm})$ であったが測定時 の接触衝撃などでヒビ割れが発生し易く, 計測誤差や 維切れの要因となっていた。

フェライトを $60 \mathrm{MIL}(1.5 \mathrm{~mm})$ 仕様に変更後, 割 れなどのトラブル発生がなく, 半年から 1 年程度の寿 命が, 3 年以上使用可能となり年間約 600 万円程度の 大幅な保全費削減となった（図 25）。なお, 厚み変更 に伴う測定值への影幚はない。

以上の改善のほか, 従来芯線の飛び出しや変形の多



図 23 部品延命化事例-2ヘッド走行モーターの国産 化

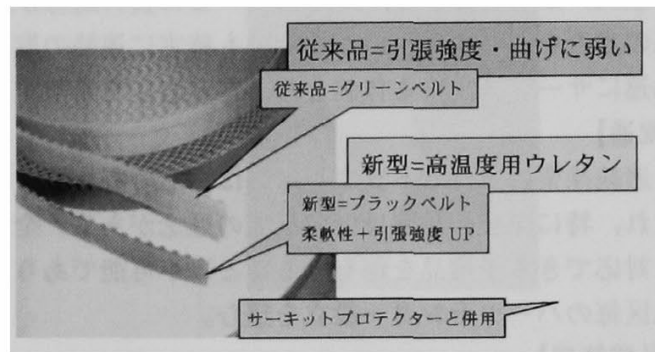

図 24 部品延命化事例 -3 走行ベルトの延命化

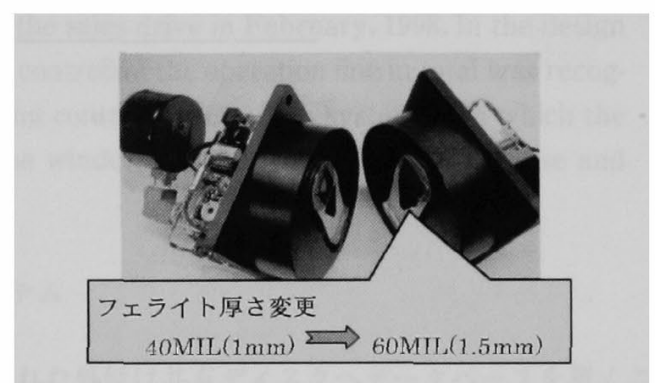

図 25 部品延命化事例 -4 キャリパーセンサー仕様変 更

かった走行ケーブルの国産化，ホースジョイント部を ヘッド手前に新設，除電用ブラケットの改良等々 20 項目以上にわたる改善・改良を加え，年間およそ 1,000 万円程度の保全費削減と, 突発故障の滅少及び 作業性向上を図ることができた。

\section{5. 保守改善に対するメーカーへの要望}

$\mathrm{BM}$ 計の長期安定稼動は計画的保全に徽することし か方法はなく，そのため我々保守する側は細かな作業 にも神経を使い, 確実性をモットーに突発故障の発生 防止に懸命な PM を実施している。

勿論, メーカーにも最大限のサービスをお願いし, 故障滅少の実績を上げてきているが，それでも重大卜 ラプルの引き金となる要因があり, 気を抜けない状況 
にある。

以下に, PM・突発故障時における対応も含めてメ 一カーへの要望をまとめた。

【技術面】

センサーや測定に関する技術は評価できるが，走行 系・駆動系個々の部品に脆弱な物があることと, 部品 交換の分解時に疑問を感じる組立てが多い。一般的な 消耗品も含め強固な部品設計と保守する側に立った設 計を切に要望する。

【保守・サービス】

重大, かつ緊急トラブル時はサービス貝の助勢が結 果の良否を左右する。いかなる時も確実に連絡の取れ, 迅速にサービス出来る体制とし，地元駐在を希望する。 【流通】

連続操業におけるトラブル対応は部品の有無に左右 され，特に深夜の故障は伤口拡大の慗念がある。全て に対応できる予備品を保有することは不可能であり， 地区毎のパーツセンター設立を望む。

【品質管理】
入手部品に仕様変更品や作動不良品及び手配ミスな どから代替えできない品が多い。確実な手配ルート， 出荷時の箃重チェック体制の確立を望む。

【改良・改善】

パーツなどの改良・改善は申し入れから実用まで時 間がかかり過ぎる。現場の意見を真槷に聞き入れ，柔 軟かつ迅速に対処できる体制づくりを望む。

6. おわりに

冒頭でも述べたように，BM 計の必要性は将来的に 不変であり，むしろ更なる発展を期待する。今回報告 した事例は,メーカーに対する苦言と感じられる内容 かも知れないが, その背景には, 常に品質の維持と安 定操業を課せられた保全マンの使命があるからである。

我々のできることは極めて限られているが, 今後と も, 少しでもシステムの長期安定稼働に役立つ改善に 取組んで行きたい。BM 計製造に携わる各メーカーサ イドにおかれても今より更に協調性を強め, 現場の㥗 み解決に向けた迅速で適切な対応を望むものである。 


\section{帮 文 概 要一筧}

\section{BM 計保守改善の取組について}

\section{王子製紙株式会社 苫小牧工場施設部 上村登黄雄}

製紙工場における BM 計は品筫維持・生産性確保に必要不可欠なッールであると同時に, 測定精度 が高く，かつ制御性・長期安定性・保守性に優れていることが肝要である。

1960 年代後半より採用された初期の BM 計は坪量・水分流れ方向制御のみであったが，以降抄紙機 の增設や各種新型センサーの開発, 幅方向制御の要求のほか, 制御機能の多様化, データー処理高速化 のニースによる機種変更を経て現在の機種に発展してきた。

しかし，保守する立場の視点で BM 計そのものを見ると，長年世代交代を繰り返しながら発展して きたにもかかわらず，センサー・フレーム駆功系，及び制御系も含めたシステム全体に，機能上まだま だ改善を必要とする点が多いのが現状であり，日常保全においてこれらの問題をテーマとして取組み， 成果を上げた改善事例として，(1)MX-BM 計フレーム歪み防止対策，(2)横河電機同軸水分計の改善，(3) オンライン検定作業改善, (4)MX-BM システム部品の延命化と作業改善等の事例を紹介するのと同時に, 技術面・保守サービス・流通・品質管理等に䦎し，BM 計製造にかかわる各メーカーサイドへの要望を まとめた。

(本文 55 ページ)

\section{新聞マシンの仕上げ操業管理システムについて}

日本製秘株式会社 八代工場動力部 大嶋 浩行

平成 10 年 2 月に営業運転を開始した八代工場 N 2 マシンの操亲ラインに, ワインター以降の仕上げ 工程と倉庫・出荷までに重点を置いた操業管理システムを構箖した。このシステムは, OSにWindowsNT を採用した DOS/V パソコンによる，クライアントサーバーシステムである。現場オペレー夕 が操作するクライアントには, 17 インチのタッチバネル CRT を採用し，操作性の向上を図っている。 沜送中の巻取個々の識別のために，バーコードシールを巻取端面と外装胴面に自動発行貼付し，ハード トラッキングを行っている。現場の数多くのブロセス機器とは，PLCと操業管理システムのゲートウ エイコンビュータを直接，光LAN でリンク接続し，リアルタイムでのデータの授受が行えるようにし た。この方式により個々の通信プロトコルを作成することなく開発工数が削減でき，さらに様々な追加 改造に容易に対応できるようになった。また巻取鏡面印字やラベルの自功䊿行貼付など包装工程から倉 庫・出荇までを管理することで，操莱の自功化や奻率化に大きく寄与するシステムが完成した。

(本文 63 ベージ)

制御系システムでの 2000 年問題 vol. 2

\section{自動化委員会（日本製紙株式会社）三浦 雅}

コンピュータ西暦 2000 年問題については，人類が初めて道遇する文明国特有の社会問題としてこの 年末年始を中心に大きな閞心を呼んだが, 結果的にはそれ程大きな障害もなく推移した。もともと何も しなくても良かったのではとの意見もあるが，担当者としては事前の周到な泍備・努力があったからこ そと思いたいものである。

本報では，紙パルフフ 10 社, 54 工场の計装関係の制御系システムを中心に，いわゆる 2000 年問題への 